\title{
ETHNIC COMMUNITIES, IDENTITY AND BELONGING: AN AUTOETHNOGRAPHY
}

by

Evanilde Bekkout, BA in Arts - Major History, Ryerson University, 2014

\author{
A Major Research Paper \\ presented to Ryerson University \\ in partial fulfillment of the \\ requirements for the degree of \\ Master of Arts \\ in the Program of \\ Immigration and Settlement Studies
}

Toronto, Ontario, Canada, 2015

(C)Evanilde Bekkout 2015 


\section{Author's Declaration}

I hereby declare that I am the sole author of this major research paper. This is a true copy of the MRP, including any required final revisions.

I authorize Ryerson University to lend this paper to other institutions or individuals for the purpose of scholarly research.

I further authorize Ryerson University to reproduce this paper by photocopying or by other means, in total or in part, at the request of other institutions or individuals for the purpose of scholarly research.

I understand that my MRP may be made electronically available to the public.

Evanilde Bekkout 


\title{
ETHNIC COMMUNITIES, IDENTITY AND BELONGING: AN AUTOETHNOGRAPHY
}

\author{
Evanilde Bekkout \\ Master of Arts 2015 \\ Immigration and Settlement Studies \\ Ryerson University
}

\begin{abstract}
This paper presents an autoethnographic analysis of identity and belonging. I describe some of my own experiences as a member of the Brazilian and Portuguese communities in order to propose that multicultural individuals need to navigate among the many identities they relate to, which make them live at the margins of cultural groups rather than limiting them to one exclusive culture. I examine the period I lived in the Brazilian community and why I do not fit there; and why I fit in the Portuguese community although I do not feel that I fully belong there. Then, I argue that a multicultural individual needs to live at the margins of cultural communities in order to move among different communities; and conclude that more work on multicultural identity is needed to understand how multicultural individuals handle belonging without identifying themselves with specific groups. The sequence of personal experiences presents a progressive development of identity and belonging culminating with an argument that this project can be enlarged into a qualitative study of identity and belonging in ethnic groups to examine multicultural identity in ethnographic studies.
\end{abstract}

Key words: Identity, belonging, Brazilian and Portuguese communities, multiculturalism 


\section{Acknowledgments}

Once a literature teacher said that to understand Machado de Assis, a classic writer of the Brazilian literature, one has to read between the lines of his writings to understand what he is really saying. Although I am not a classic writer, I could not have developed this project if my supervisor Dr. Vappu Tyyskä had not looked beyond the surface of an idea and discovered sufficient material to transform the idea into a palpable project. After that, she continued to guide and support me with valuable tips to transform this paper into a potential source of research to those who are interested to study more about identity and belonging among ethnic groups. Since the idea of this project started during one of my classes of the Immigration and Settlement Studies Program, I was thrilled when Dr. Amina Jamal, my Professor, accepted to be part of this project as the second reader. Finally, I would like to mention my husband, who has been patient and understanding throughout this whole process, and has never pressured me that I had dinner ready when I had to research or to write to complete a section of this paper. I am truly thankful to you all for the special ways you have contributed to make this project possible. 


\section{Table of Contents}

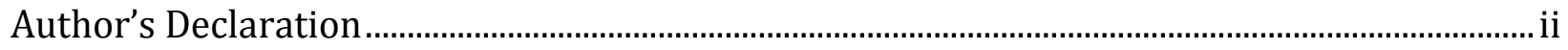

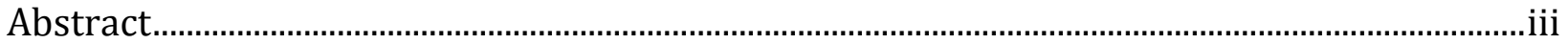

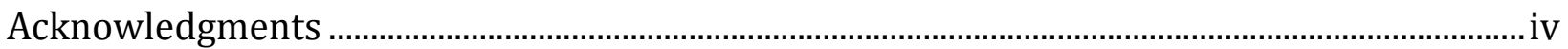

Introduction

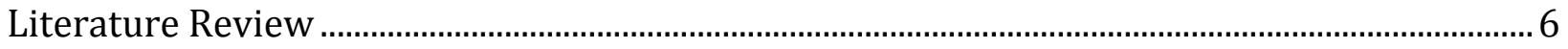

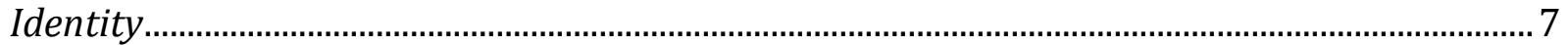

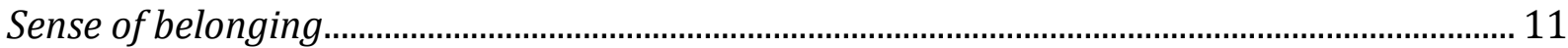

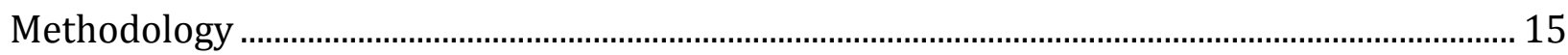

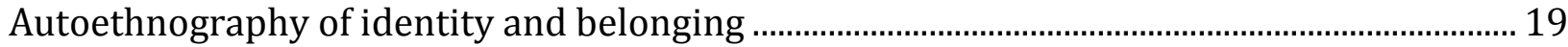

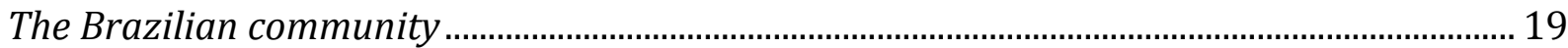

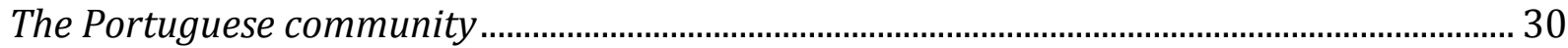

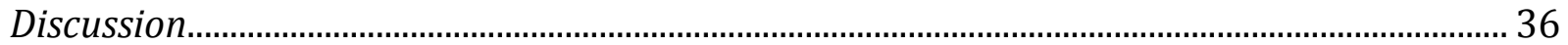

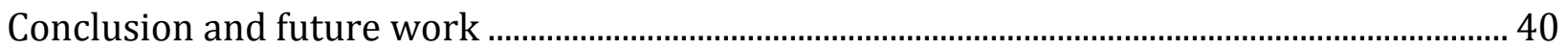

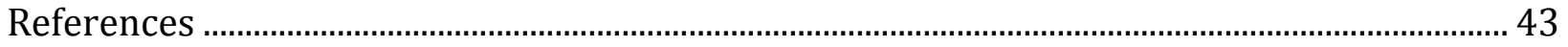




\section{Introduction}

My ethnic identity is usually challenged because of my accent. When I was visiting Chicago, a woman asked me where I had come from and I automatically said Canada. She did not accept my answer and we started discussing about citizenship, until I gave the answer she expected: I was born and raised in Brazil; therefore, I could not be Canadian because my mother tongue was Portuguese, not English. In many occasions when I was in Britain, people were satisfied when I said I came from Canada. They did not argue or debate about accents and citizenships; they accepted my answer without challenging it. This shows how people's curiosity about these matters depends on the context. In Canada, identity and belonging are greatly discussed, and many people sound confused when questioned about their ethnic and cultural identities. Before going any further, it is important to say that my contact with Canadians is limited to the Great Toronto Area (GTA) and to information from books, lectures, and the media.

The discussion of identities seems to have a link to the sense of belonging individuals have within their ethnic and cultural communities, independent of their actual immigrant status. According to Statistics Canada (2014, para. 2), the ethnocultural characteristics of the population are categorized according to "origins of various waves of immigrants who have settled in Canada over time," and analyzes the Canadian population based on its generation status, which refers to "whether people are first, second or third generation or more in Canada." The first generation refers to those who are born outside of Canada; the second generation refers to those who are born in Canada, but have at least one parent who is non-Canadian-born; and the third generation or more refers to those who are born in Canada, and their parents are also born in Canada (Statistics Canada, 
2014). The 2011 Census shows that 22 percent of the Canadian population is first generation, which means that 78 percent are Canadian-born (Statistics Canada, 2014). Perhaps these terms first, second and third generations have something to do with my interpretation of people being confused, since I relate ethnic identity to nationality: I was born in Brazil, therefore I am Brazilian. You are born in Canada, therefore, you are Canadian. This concept made sense to me when I lived in Brazil, but since the concepts of identity and belonging are discussed under the ideology of multiculturalism in Canada, they are more complicated to grasp; hence my desire to embark on studying these concepts in depth.

In multicultural cities, such as Toronto, Montreal and Vancouver, many people are asked about their ethnic identification, which makes them aware of belonging to a specific group. Some say they belong to a minority ethnic group, others say they belong to a mainstream ethnic group, and still others say they belong to both or to neither of them (Berry \& Sam, 1997). This fluctuation of identity and belonging is arguably accepted in Canada, which can be seen through the government endorsement of multiculturalism policy since 1971, which led to the creation of the Multiculturalism Act of 1985. The Act recognizes and promotes "the cultural and racial diversity of Canadian society and acknowledges the freedom of all members of Canadian society to preserve, enhance and share their cultural heritage;" as well as encourages "the understanding that multiculturalism is a fundamental characteristic of the Canadian heritage and identity and that it provides an invaluable resource in the shaping of Canada's future" (Government of Canada, Nov. 25, 2014, Part III). 
The government's attempt to recognize Canadian multicultural diversity is commendable; however, how this characteristic is apparent in individuals and how it is embraced by them has not been exhaustively studied in ethnic and cultural fields. I observed this gap in the literature when I researched the topic of identity for this paper. Even before that, in classes on Canadian history, culture and immigration, the discourse of multicultural identity was not introduced when identity and belonging were discussed. This reality may have negative consequences because Canada has a history of questioning the identity of its population. For example, the Chinese community was present in Canada before the Confederation; however, it was only in 1947 that the government created the necessary immigration policy that promoted the naturalization of the Chinese population as Canadian (Hawkins, 1988). Another example is the internment of Japanese and Italian descendants during the Second World War, which made these Canadian-born communities, among others, to be considered 'enemies of the state' (Kelley and Trebilcock, 2010).

Even more intriguing is that Canadian-born people, especially those who do not come from settler or Aboriginal ascendancies, have difficulty claiming to be Canadian, despite the historical episodes relating to identity issues. As a person that comes from a colonized country and recognizes the ethnic diversity of my own heritage, it never crossed my mind to identify myself with my ancestors' places of origin. In fact, I was never confused about my identity before; I knew where I belonged before arriving to Canada. Even when I left my city and then my state in Brazil, I knew exactly what ethnic and cultural communities I belonged in. However, as an immigrant in Canada, I have experienced a great deal of confusion over cultural identity, although not as much as ethnic identity: I am gaúcha to Brazilians because I came from the extreme south of Brazil, and I am Brazilian to 
non-Brazilians. The cultural characteristics I have are not the same as those of the Brazilians I met when I immigrated to Canada, which makes the discussion of identity and belonging much more complex than before I left Brazil. This fact was evident when I tried to interact with members of my own ethnic group and could not identify myself with them as I expected. I left the Brazilian group and mingled with a Portuguese community, in which I am an active member for over 10 years now. Although I questioned the reason why I left the Brazilian community for many years, I did not understand that this reason was related to identity and belonging, and that I was facing the same confusion that I perceived among Canadian-born people.

It was in one of my classes of the Immigration and Settlement Studies Program, in which the discourses of identity and belonging were debated that I realized that since I had struggled to fit into my own ethnic community, I could explore this 'identity confusion' through my own experience. I started to remember some of the situations in which I could not let myself behave or act the way the Brazilian group expected, and this resistance created a gap between us that I could not reconcile. I did not belong to that group; therefore, I left it, and although I fitted better in the Portuguese community, I really did not want to belong to an ethnic group. If I am to choose, I prefer to identify myself with the characteristics of those who feel comfortable claiming to belong to both minority and mainstream groups, which may be one of the characteristics of multicultural identity.

The ability to belong to a diverse society as Canada claims to be, sounds like an important skill for a person to develop, which seems to be my case as I understood when engaging in the research for this paper. Thus, I describe in this paper some of my own experiences as a member of the Brazilian and Portuguese communities in order to propose 
that multicultural individuals do not belong in defined cultural communities because they live at the margins of many cultures. This ability helps them to navigate among the many identities they relate to, which assert them as multicultural individuals. I use the autoethnographic methodology to relate my experiences with both communities' developments. I examine the period I lived in the Brazilian community and why I did not fit there, although I am Brazilian "by default"; and why I fitted in the Portuguese community although I do not feel that I belong there. Then, I initiate a discussion on multicultural identity and the lack of study to understand multicultural identity and its characteristics. I present my autoethnography as a progressive development of identity and belonging culminating with an argument that this project can become a larger scale qualitative study of identity and belonging in ethnographic studies focused on examining multicultural identity in depth. 


\section{Literature Review}

The academic interest in identity and belonging flourished in the 1970s, with a proliferation of theories of ethnicity, explaining such diverse phenomena as identity formation and assimilation (Barnard \& Spencer, 2002). The constructivist approach, which argues that the interaction of humans' experiences and ideas generates knowledge and meaning (Eddy, 2004), can be used to explain the variation of these definitions in the social sciences. For example, I consider ethnicity as a categorization of race (phenotypical characteristics) and nationality (geophysical borders). However, other scholars include many more elements to define ethnicity, and in doing so, they include cultural elements as well. For example, Cohen (1978, as cited in Barnard \& Spencer, 2002, p. 293) defines ethnicity as "a set of sociocultural diacritics [physical appearance, nomenclature, language, history, religion, and nationality] which define a shared identity for members and nonmembers; a series of nesting dichotomizations of inclusiveness and exclusiveness."

Nevertheless, ethnicity comes with a macro interpretation of countries and nations, while culture is related to traditions, customs, beliefs, behaviours, and other features manifested in the populations inside these countries and nations. The English anthropologist E. B. Tylor, who introduced the term culture into academia in 1871 (as cited in Rocher, 2015, para. 5), defines culture as "the complex whole which includes knowledge, belief, art, law, morals, custom and any other capabilities and habits acquired by man as a member of society." This definition has not changed much over the years, although some scholars have come up with new ways to say the same thing, describing culture as the assembly of thoughts, practices and behaviours acquired through the exchange of experiences and practices that distinguish groups and give them a distinct collectivity 
(Rocher, 2015). In this paper, when I refer to ethnic identity, I am thinking of nationality (e.g. Brazilian) and language (e.g. Portuguese), while when I refer to cultural identity I include everything else (e.g. customs, beliefs, behaviours).

\section{Identity}

The debate of identity has become a heated topic in the current interconnected world. Weinberg (cited in Bauder, 2012, p. 185) says that "identity is multi-faceted," in that "an individual can identify with more than one group in multiple levels." Iyall Smith (2008) argues that this process of identification tends to produce differentiation, assimilation or hybridization among ethnic groups. Differentiation involves the process of excluding certain individuals because they have fewer similarities with the dominant group (Vallee, Schwartz, \& Darknell, 1957). Assimilation emphasizes the diminution of distinct characteristics of individuals, which make them conform to the dominant values of the majority of the group (Verkuyten, 2011). Hybridization refers to the separation from existing practices to embrace new practices that create new cultures and, consequently, new identities (Iyall Smith, 2008).

According to Iyall Smith (2008, p. 5), hybrid identity "might allow the globe to unite in its differences, to be a truly multicultural society that is able to recognize and reconcile diversity." This blending of multiple cultural categories causes new hybrid identities to emerge. There are many hybrid identities that scholars rely on, to explore how people identify themselves, such as 'third space,' 'duality,' 'borderless' and 'gender' identities (Iyall Smith, 2008). However, I chose the terms monocultural, bicultural, and multicultural identities, from the works of Taylor (2006) and Yampolsky, Amiot, \& de la Sablonnière, 
(2013), to help me to examine the concept of cultural identity because of their succinct and distinct definitions. Each concept is supported by unique characteristics that do not overlap with one another, which facilitates the argument I am making in the paper.

Monocultural identity overvalues its own cultural beliefs and practices, while it invalidates other cultural worldviews (Taylor, 2006). According to Jantzen (2009), less than $30 \%$ of Canadian citizens belonging to the second generation are from British or French origin only. This means that, excluding First Nations peoples, over 70\% of the population, whole or partially, originates from other places around the world, which creates a complex dynamic among urban populations (Vertovec, 2007). Nevertheless, there is still the strong sense that Canada is British or French, according to ethnic identification, rather than multicultural as expressed in the government's recognition of the country's diversity (Kelley \& Trebilcock, 2010). For example, without the assumption that 'true' Canadians are Caucasians, there would be no way to categorize Canadian-born people as ethnically distinct. Indeed, who could say that two teenagers, for example, who wear the same style of clothes, listen to the same type of music, and are both fans of hockey, have to identify themselves with Bangladeshi and British ethnicities without societal imposition?

For the past twenty years, more precisely, researchers have focused more deeply on how bicultural and multicultural people integrate their different cultural identities within themselves, and how they subjectively reconcile these different identities in order to interact with others (Noels, Pon, \& Clément, 1996; Haritatos \& Benet-Martínez, 2002; Downie, 2004; Tadmor \& Tetlock, 2006; Yampolsky, Amiot, \& de la Sablonnière, 2013). Bicultural identity is shared by those who hold strong cultural identification with two cultures anticipating the result of being accepted by the cultural group that is not seen as 
their own (Fearn, 2006; Smith, 2008). Notice that the word anticipating is a feeling, an expectation, a wish that something happens according to the individual's emotion: this anticipated conflict may or may not happen, as I have told with my experience in Chicago and Britain. Bicultural individuals also develop strategies to use in response to cultural conflicts between two sets of cultural norms, values, or practices (David, 2006). Noels, Pon, and Clément (1996), for example, highlighted how bicultural people will 'frame switch,' or shift from one set of behaviors to another, depending on the context, as a way to manage these different cultural identities. This interpretation would explain why some individuals fluctuate between two identities. In order to be accepted and avoid conflict they prefer to identify themselves with their parents' ethnicity rather than provoking a discussion that they may not be ready to debate, such as racism and discrimination.

I have observed a certain degree of identity struggle when Canadian-born people say they are Canadians after identifying themselves as belonging to their parents' ethnicity. I remember asking a Canadian-born peer why he claimed to be Jamaican when he was born and raised in Canada and had never visited his parents' country. He said that he felt pressured during his adolescence to claim to be an immigrant because those who asked about his ethnic identity would not accept that he was Canadian. He just got tired of arguing about the topic and wanted to avoid a long debate on identity. As a child, he never had to deal with ethnic identity because he never saw himself as different from his friends.

The documentary One Big Hapa Family (2010), by director and producer Jeff Stearns, shows that Japanese-Canadian children interviewed in the movie created the word hapa to identify their bicultural heritage, as an alternative to the more conventional forms of identifications. Because the Japanese descendants who lived in Canada during the 
Second World War were sent to internment camps as 'enemies of the state' (Kelley \& Trebilcock, 2010), Canadian-born children of these families bond themselves to Canada through marriage outside of their ethnic group. Since they have Japanese and other heritage, hapa became their new form of identification. Are other Canadian-born people finding some alternative words to identify themselves so they can claim they belong to Canada, but not to the conventional nomenclature?

Finally, multicultural identity is shared by people who "often need to navigate the different norms and values associated with their multiple cultural identities" (Yampolsky, Amiot, \& de la Sablonnière, 2013 [italics added]). The word need implies a necessity, a compulsion, a must, and to navigate suggests a constant movement from one place to another. Notice that the language used for multicultural individuals is not the same as when it referred to bicultural individuals. This suggests that a different perception has developed to explain multicultural identity that has been significantly embraced by individuals due to the increase of migration and globalization (Sam \& Berry, 2006). Multicultural identity is manifested among individuals who are actively involved in both mainstream and the heritage cultural groups (Yampolsky, Amiot, \& de la Sablonnière, 2013). One of the interviewees in Yampolsky, Amiot, and de la Sablonnière (2013, para. 34) research, who has parents that are Lebanese and French, was born in the United States, and moved to Montreal during his childhood, explains how he has adapted to his cultural contexts while claiming to have multicultural identity, "if I need to be American, I'm in here... Certainly when I am talking to a Lebanese person, and I have multiple cultures behind me, I do feel a bit more Lebanese at that specific time, just at that specific time. But that doesn't mean that the rest of it is gone. No. You are going to use the rest of that to, you 
know, make the conversation more interesting. Soften the mood, make them feel more welcome." Thus, the ability to relate with another person becomes more palpable because of the similarities the multicultural individual has due to his/her own diversified identity.

In the developmental psychology literature, several scholars have highlighted the importance to understand the dynamic nature of cultural identification, and how it is subject to change over different phases of life as their patients integrate in the mainstream culture (Phinney, 1989; Harter \& Monsour,1992; Harter \& Whitesell, 2003). According to Pieterse (2001), it is the interaction of these diversified ethnic populations that produces multicultural groups and generates blending capabilities, since people's experiences are influenced by multicultural heritage as well as by interacting with people outside their ethnic communities. This means that multicultural individuals, who navigate between different cultural groups, apply these capabilities to negotiate and integrate differing expectations, norms, values, and practices associated with their multicultural identities so they can fit in each group (Giguère, Lalonde, \& Lou, 2010; Yampolsky, Amiot, \& de la Sablonnière, 2013). They believe that helping individuals to understand how to develop and manage these capabilities will facilitate their integration in the mainstream culture, which is identified according to the population that lives in a specified region (Poirier, 2012; Fearn, 2006; Green, 2003).

\section{Sense of belonging}

Sense of belonging involves "the feeling, belief, and expectation that one fits in the group and has a place there, a feeling of acceptance by the group, and a willingness to sacrifice for the group" (McMillan \& Chavis, 1986, p. 10). When people feel accepted they 
can make statements such as 'it is my group,' which indicates that they identify themselves with the group and is 'one of them' (McMillan \& Chavis, 1986). There are many groups that people can identify with and, therefore, develop a sense of belonging. For example, they can be part of a family, a school, a profession, a nation, a religious lifestyle, a human rights organization, etc. Since they all have an identity, which is extremely important for living in a society because it gives a sense of affiliation and loyalty, it is necessary to understand what identity people refer to when they are claiming their identification (Sen, 2006). When this identification is not clear, people can be ambiguous in their answer about belonging. This ambiguity can be seen in the current numbers of the government in measuring Canadians' sense of belonging.

The 2013 General Social Survey on Social Identity asked immigrants and Canadianborn people aged 15 years and older to describe their sense of belonging to Canada, their province of residence and their local community (Statistics Canada, 2015). The numbers show that 63 percent of participants claimed to have a strong sense of belonging to Canada, 45 percent said they had a strong sense of belonging to their province and 32 percent felt a strong sense of belonging to their local community (Statistics Canada, 2015). Immigrants (67 percent of participants) claimed to have a very strong sense of belonging to Canada in comparison to Canadian-born (62 percent of participants, which may indicate a stronger provincial than national affiliation). Among the immigrants who have been in Canada before 2000, 71 percent claimed to have stronger sense of belonging in Canada while 60 percent of immigrants who have come to Canada between 2000 and 2013 claim to have a strong sense of belonging to Canada (Statistics Canada, 2015). The report does not show the total number of participants, although it indicates that the survey included the ten 
provinces. Although the survey does not explain what kind of identification people are thinking of, the Statistics Canada (2010, para. 2), states that sense of community belonging "embodies the social attachment of individuals and reflects social engagement and participation within communities." This definition suggests that the majority of immigrants has successfully integrated and participated in their communities, which explains the strong sense of belonging in Canada. Since the survey does not clarify which community the participants claim to belong, it appears correct to assume that they have strong connection with their ethnic communities rather than with the mainstream Canadian culture.

According to Lambert, Stillman, Hicks, Kamble, Baumeister, and Fincham (2013), sense of belonging has a strong correlation with the perception of living a meaningful life. Klinger (1998) argues that a meaningful life means that one lives a purposeful existence generated by the ability of the brain to create thoughts that are fundamental to humans' lives. The measurement of meaning in a person's life depends on how the individual perceives his/her relationship with others (Steger, Frazier, Oishi, \& Kaler, 2006). Researchers have found that people who are socially rejected experience a decrease in meaningful thought, which may lead to loneliness, depression, and exclusion (Twenge, Catanese, \& Baumeister, 2003; Williams, Cheung, \& Choi, 2000; Stillman, Baumeister, Lambert, Crescioni, DeWall, \& Fincham, 2009). Hogg (2009) argues that humans have a biological need for social relationships, and that close relationships allow people to feel a part of a larger symbolic entity, from two persons to larger groups, which reduce feelings of uncertainty and disorder. In fact, the sense of belonging shared in social groups can provide stability, create a sense of shared identity, and when they form and achieve collective goals, 
it results in making people's lives meaningful and worthwhile (Haslam, Jettem, Postmes, \& Haslam, 2009).

Nevertheless, people have to share the same worldview in order to build their group identity and claim that they truly belong to their group, which evolves from their similarities, such as language, history, place of origin, and culture to personal gratification and goals. According to Dana (1998, p. 16) “worldview is a cultural construction of reality that has developed as a basis for sanctioned actions to permit survival and adaptation under particular shared living conditions, geographic circumstances, and catastrophic events." Immigrants share similar worldviews in terms of belonging to a "particular group and ha[ve] pride in one's group identity," making ethnic identification the "primary focus for group identity" because the new immigrant carries "values, beliefs, language, behaviours, and customs" that seems very close to the one longer-term immigrants think they still have (Dana, 1998, p. 17). 


\section{Methodology}

The use of one's own experiences to investigate social life is called autobiographical method (Lewis-Beck, Bryman \& Liao, 2004). Autobiographical work examines an individual's life and how it impacts on other people's lives. For example, Nelson Mandela (1995) wrote his autobiography, in which he tells his life's experience from his childhood to his South African presidency. This method is part of a more general biographical approach within the social sciences, in which researchers are focused primarily upon the ability of individuals recollecting, by memory, specific events, emotions, feelings, time, situations and interactions they lived in the past (Roberts, 2002).

According to Roberts (2002, p. 1), biographical research "is an exciting, stimulating and fast-moving field which seeks to understand the changing experiences and outlooks of individuals in their daily lives, what they see as important, and how to provide interpretations of the accounts they lived of their past, present and future." Since autobiographical method relies on memory, it is important to say that the considerations relating to the self, emotions, goals, and personal meanings of current review intersect with the emotions experienced during the time the event occurred and may give a different interpretation of what happened in the past (Holland \& Kensinger, 2010; Friedman, 2004). This means that the accuracy of the narrative is subjective to the emotions people are experiencing during the time they are remembering the event rather than when they were living in the situation in the past.

Although I will use the autobiographical method in recollecting and writing some of the events that I lived in the past to discuss identity and belonging, my goal is to focus on the groups' identities in comparison to my own. This means that both the community's 
description and my experience are important in the narrative, which expands to an ethnographic work rather than an autobiographic paper. The study of identity and belonging in ethnic groups is part of the relatively new interdisciplinary field called ethnography. Nevertheless, the study of communities is not new. For example, in 1925, the anthropologist Margaret Mead spent approximately nine months among Samoans in a field work, which resulted in writing the very popular book Coming of Age in Samoa (1928).

The simplest definition of ethnography is found in Poulos essay Autoethnography (2013, p. 39), in which he explains that the term comes from the roots ethnos=people and grapho=writing, and means "writing about people." Tedlock (2003, p. 165) describes ethnography as a combination of "research design, fieldwork, and various methods of inquiry to produce historically, politically, and personally situated accounts, descriptions, interpretations, and representations of human lives." Thus, ethnographers have to form relationships with their subjects of study in the research process in order to "understand the cultural variation of/and human universalities" (Kendall \& Thangaraj, 2013, p. 83).

Therefore, it is very common for ethnographers to be actively involved in the communities they are studying. However, in order for them to keep focused on the lives they are studying, they detach themselves from their subjects (Poulos, 2013; Goodall, 2000; Denzin, 1997; Crawford, 1996; Geertz, 1973). Some researchers become so focused on this detachment that they ignore the feelings, emotions and even the human fragility that compose people's lives, including personal interaction on the everyday life of the community, researcher's knowledge, and emotional response to the exchange of experiences (Merril \& West, 2009; Poulos, 2013). In other words, they ignore that the community is reacting in a certain way because of the presence of the researcher there. For 
example, imagine that two neighbours are discussing the position of a fence between their properties. They have been unable to come to terms on the issue for years and frequently end up in fights when they discuss the matter. In the middle of one of the heated discussions, which certainly might have end up in punches being equally distributed, the researcher passes by and engages the neighbours into a conversation. They are embarrassed and decide to call for a truce until the researcher leaves the community. They can also compromise and end the discussion once and for all. Whatever the result, it occurred because of the researcher's presence in the moment.

Thus, researchers created the autoethnographic style in qualitative inquiry in order to recognize the impact of the researcher's presence among the community that has been studied. Carolyn Ellis, a pioneer in autoethnography, and her colleagues define it as "an approach to research and writing that seeks to describe and systematically analyze personal experience in order to understand cultural experience" (Ellis, Adams, \& Bochner, 2011, p. 1). Thus, autoethnographies allow researchers to acknowledge the influence that their experiences, responses and impressions have made within the communities they study. To use Poulos (2013, p. 51) description, "the autoethnographer reveals him/herself, and the emotional, intellectual, imaginative, and social contours of the lifeworld of which he/she is an active, engaged inhabitant."

I want to include my own experience in this paper because I see myself as both a researcher and a participant in the analysis of identity and belonging. Through my own experience I will argue that I am a multicultural individual and it may be the reason why I struggled to fit in the Brazilian community and do not belong in the Portuguese community as well. This characteristic may also be found among Canadian-born people; however, only 
an ethnographic field work will be able to clarify if my assumption is correct. For now, I will rely on literary sources as well as oral stories that I heard over the years by members of both Portuguese and Brazilian communities to conduct my analysis. Since oral stories also rely on memory and interpretation and tend to be subjective, the way I interpret my interaction with these communities may not be agreeable to other people. If asked, they may remember and then tell the same events according to their worldview, which help them to express their own experiences and emotions. The one-sided view and the new rationale that are applied in this analysis create a limited work; however, my intention in this paper is not to claim the veracity of events I lived, but to open the discussion on adding the discourse of multicultural identity to belonging and identity ethnographic and cultural studies. 


\section{Autoethnography of identity and belonging}

The experiences I will tell to discuss identity and belonging are the experiences that made me question my own cultural identity and belonging to both Brazilian and Portuguese communities in Toronto. I will start with the Brazilian community, which I briefly tell the historical movement of immigration to Brazil and emigration to Canada. Then I will move to the history of the Brazilian centre and its members. It is important to say that the identity the members developed due to their experience of immigration also exclude them from other Brazilians groups in Canada, which was one of the reasons I could not adjust to their new cultural identity. Additionally, I will include my own experiences of migration that started in Brazil to argue that my detachment from my own ethnic group started even before I came to Canada. This experience of migration also made me distinct from other Brazilians, and made me to acquire multicultural characteristics that I was not aware of while I was frequenting the Brazilian centre. Finally, I will tell about my experiences with Brazilians who made me wonder why I would not fit with the Brazilian community. I will follow the same structure with the Portuguese community, and then explain why I fit better among its members. I will include this section examining identity and belonging to show that I developed a multicultural identity, which makes me live at the margins of both cultures. This ability helps me navigate among the many identities I relate to, and help me understand who I am in Canadian society.

\section{The Brazilian community}

Brazil, like Canada, has a long history of immigration. The Brazilian population is enriched by a long-standing ethnic diversity, first with the Aboriginal peoples that the 
Portuguese encountered when they arrived in Brazil in the sixteenth century. The next phase of immigration was with the slave trade of the seventeenth and eighteenth centuries, which thousands of Africans were brought to Brazil to work in the agriculture. This was followed by more European and Asian immigrants in the nineteenth and twentieth centuries, when slavery was prohibited and labour was needed (Brasch, 2007; Bassanezi, 1996; Berquó, 2003). Political exchanges and economic trade, especially the Mercosul (Southern Common Market) continued to facilitate the constant entrance of immigrants in Brazil (Brasch, 2007). Nevertheless, an extensive history of mobility is also found internally; people constantly move from one region to other seeking better opportunities to have economic stability and to elevate their standard of living. This migration process exposes local population to different cultures, ethnicities, customs, idiomatic expressions, among others, and creates "challenges for interaction" and for continuously "negotiation of similarities and differences between people" (Brasch, 2007, p. 92).

In contrast, the emigration process started slowly, mostly by migrants returning to their country of origin or moving to neighbouring countries in Latin America (Brasch, 2007). However, political and economic crises in Brazil in the 1980s and 1990s motivated thousands of Brazilians to leave Brazil to go to other parts of the world, especially to Japan and to the United States (Vidal, 2000; Nunes, 2002; Brasch, 2007). The immigration restrictions applied to supress the flux of Brazilians to the United States made Canada an alternative immigration destination, especially to the cities of Toronto, Montreal and Vancouver (Barbosa, 2009). Even after Canada imposed visas on Brazilians in 1987, Brazilians continued to come to Canada because of employment opportunities and less 
discrimination that Brazilians encountered in comparison to the United States (Goza, 1994).

The Brazilian communities formed in Canada reflect the impact of these movements and reveal similar social strata of Brazil's composition. Before the 1980s, the majority of Brazilian immigrants were the wives and children of Canadians who worked in Canadian firms installed in Brazil. Some came as workers of transnational firms, and a few others came as independent immigrants seeking to make money to take back to Brazil or to bring their own families to Canada after finding regular employment and stability. These groups form the upper and middle classes of the Brazilian communities in Canada. They also fit the Canadian immigration policies and have the means to comply with Canadian immigration restrictions (Magocsi, 2015).

During the 1980s and 1990s, a significant change of immigration patterns happened. Motivated by the social services that Canada offered to its citizens, thousands of Brazilians, including a great number of young men without post-secondary education, came as tourists or refugees (Shirley, 1999). Social services were advertised by a few travel agencies located in the cities of Governador Valadares and Ipatinga in southeastern Brazil. The agents financed the flights, provided fraudulent documents, and coached some of the applicants about Canadian refugee laws to attract their interests and encourage them to immigrate (Magocsi, 2015). Brazilians continued to immigrate to Canada in the 2000s, however, the more recent group of immigrants were from middle and upper classes, favoured by immigration policies (Statistics Canada, 2012).

The Brazilian community that I affiliated with after immigrating had a mix of people who came to Canada between the 1970s and 1990s. The majority of them came from the 
south east region, mainly from the states of São Paulo and Minas Gerais. They shared similar experiences before and after arriving in Canada: they were young families or single men who had never lived outside of their cities in Brazil and left the country because of the economic crisis, which made it hard to find employment to support their young families in Brazil. Once in Canada, they first settled among the Portuguese community, following the pattern of other Brazilians across the country who were attracted to Portuguese communities by language and historical relationships (Teixeira, 2007). The Portuguese helped these immigrants to settle down and find housing, jobs, as well as to understand Canadian practices and customs. Although this relationship between Brazilians and Portuguese was helpful in settling down and to adapting to the new homeland, Brazilian immigrants faced many challenges to legitimize their civic status, and had strong transnational practices, such as sending money to their families and building houses to go back to when they could leave the country.

Their distinct ethnic and cultural characteristics brought the Brazilians together making them develop a sort of kinship relationship, which led them to open a community centre in 1990, focused on helping other Brazilians who were steadily arriving during the same period. The changes in immigration policies in the late 1990s slowed down the Brazilian immigration to Canada (Teixeira, Li, \& Kobayashi, 2012), and the characteristics of immigrants who sought the centre also shifted. Many immigrants came from the middleclass and held professional experiences that were attractive to Canadian employers. They could become immigrants as independent applicants, following the requirements of the immigration policies in place, and they did not have to face the same challenges as the previous arrivals. 
When I arrived in Toronto in 2000, a friend of mine, who was living in the city at the time, told me about the centre. I was attracted to the centre because of the chance to do volunteer work and help others in need. Once I started to frequent the centre, and got more familiar with the members, I could see how united they had become: they shared everything, including their hopes and frustrations in interacting within the Canadian society. One of the hopes they had was to become legalized residents. Many of those who arrived until the 1990s took advantage of the immigration program, known as Administrative Review Program (ARP). This program was serving primarily the construction sector that was booming during the late 1980s (Brasch, 2007), and the majority of male members worked in construction. Brasch (2007) explains that this program was hastily developed to deal with the flood of refugee applications from Brazilians and other immigrants. The ARP's rules changed constantly, making it difficult to follow, however, those who applied and completed the requirements received their landed status. The program ended in the early 1990s (Brasch, 2007), probably as a result of the 1990-91 recession that hit the construction industry hard (Dzialo, Shank, \& Smith 1993). Differently from the majority of members, I came to Canada to acquire international experience and was ready to go back to Brazil by the end of my visit.

Nevertheless, in the Brazilian group in Toronto, I was the only person who came from Rio Grande do Sul, and had an extensive experience in migration, which set me apart from the recent group of immigrants that frequented the centre as well. Before coming to Canada, I had lived in four different states in Brazil, and I was relentlessly asked from where I had come because of my regional accent. Even before leaving Rio Grande do Sul people asked me if I was paulista (people from the city of São Paulo) because of the way I 
pronounced the ' $\mathrm{R}$ ' in the words, which was different from how gaúchos pronounce it. When I left the state, I fully embraced this 'foreignness' and even had some fun along the way: since people did not know the regional ethnicity, gaúcha, I liked to use this answer to see if they knew the name of the state from where gaúchos come. They usually named the other two states of the south region first, until they came up with the right one. This 'mistake' made me realize that people just stereotyped gaúchos and did not really understand their cultural traditions. Nevertheless, I did not feel that I was discriminated for coming from the south, but enjoyed myself as I tried to adjust to the cultural differences I encountered among the locals.

One of the reasons that I left Rio Grande do Sul was that I started to challenge the cultural characteristics of the population. I did not like the patriarchal tradition (see Heath \& Ciscel, 1988) gaúchos were so proud to have. For example, for gaúchos women had to prioritize having children and being housewives; and if they had to work outside, they had to manage the work between their jobs and their families. I wanted a career and to travel a lot before settling down with a husband, but not necessary into motherhood. I liked the idea of breaking away from set roles to a more integrated division of labour in the family and in society. I thought that going to another state I could break free from this concept and observe the family structure of other cultures. During the period I moved from one state to another, I observed and compared how people acted on and expressed their values, which made me evaluate what characteristics I wanted to imitate and what elements I wanted to discard. One of the things I admired on baianos (people from the state of Bahia), for example, was how they treated everyone equally despite their economic or social classes. Their friendly and genuine behavior towards me made me revaluate how I thought of 
others as well. To this day, I continue to involuntarily use the idiomatic expression ôxe [a colloquial word used in sentences, which exists only in Bahia], to express surprised or happy emotions. When I moved to São Paulo, two years later, I perceived a certain air of disdain towards northern people that I did not like, so I cut my time short and left the place after a little over a year.

This constant interaction with other cultures, although they were regional, made me develop a multicultural identity that I was not aware that I had, until I researched the topic to this paper. Pieterse (2001) describes that multicultural people develop the ability to blend in different ethnic groups since they are influenced by the culture of these groups. I blended well with the baianos and may have stayed longer with the paulistanos (people from the state of São Paulo) if I did not have the chance to move again. This movement can also be explained by the need to navigate between different groups. When I started to move from one state to another, I realized that the influence I received from other cultures while in contact with them was producing a gap between myself and the gaúcha culture. When I meet Brazilians in Canada, they tend to ask me if I use the idiomatic expression tchê [a word used to end sentences, like the Canadian expression $e h]$, and I answer that I use it rarely, usually to express annoyance with someone. A few months ago, when I was talking in Portuguese with a Brazilian student, who recently arrived in Canada, I said ôxe in some point of the conversation, but I never said tchê, which just confirmed what I had told her that I used more baiana expressions rather than gaúchas.

In Canada, the ethnic identity Brazilian became the right answer to explain the 'foreign accent' among non-Brazilians; however, non-Brazilians do not know how Brazilians are beyond their love for soccer, samba and beaches. Stereotypes are common in 
any society, since countries sell their images internationally through specific elements. For example, Canada is a place of cold, fur (Knowles, 2007) and polite people, although not everyone is polite. In my case, I do not follow soccer, I do not dance samba, and I have been on a Brazilian beach only when I lived in the state of the Rio de Janeiro because the city was located on the Atlantic coast. When I say to non-Brazilians that I do not follow soccer games, their faces and tone of voice demonstrate frustration and disappointment. This reaction is strange to me because I feel that I am pressured to fit into this stereotype that non-Brazilians have about Brazil. This pressure limits my amalgamation with the Canadian culture, which I am trying to integrate since I chose Canada as my home fifteen years ago. In contrast, I did not feel the pressure to limit myself to certain expectations when I was living among baianos, paulistanos, and fluminenses (people who come from Rio de Janeiro).

During many years, the pressure to fit these expectations in Canada bored me because I was not used to them in Brazil. Speaking and behaving differently from the stereotypes of gaúchos made me feel as if I had transcended to another level of knowledge and this feeling was satisfying: I felt that I belonged to that group of people who did not limit themselves with stereotypes, prejudices and discriminations. I had expected that Canadians would be in that level of knowledge that I had acquired because of the way they claim to be free to celebrate their cultural diversity. However, the population is segregated into ethnic groups connected with foreign lands rather than being united as multicultural individuals. Perhaps, if multicultural identity is explored in academia and its process is better understood, this knowledge may take Canadians to embrace multiculturalism in full and it becomes a way to identify Canada through culture instead of an ideology and policy. 
The Brazilian community that I joined also imposed some pressures that were unfamiliar to me. The regional identity was irrelevant among them, as it was in Brazil, but I felt pressured to develop a familial sentimentalism that they developed through the experiences they had as immigrants. This familial sentimentalism was caused by the fact that they did not have extended family in Canada making them consider the members of the centre as their family. As a family, all members had a say on particular situations, decisions and choices. The board of directors discussed how the centre was to reward, help or reprimand someone according to the situation or challenge brought to their attention. For example, if a family was in need, because the breadwinner of the household got sick, the board stipulated monthly amounts of funds to help the family until the member of the household could provide for the family again. Practices like this generated a loyalty between the members that was hard to break or contest.

When I married a non-Portuguese speaking person without informing them about it, the differences between the rest of the members and me became evident. I was already a regular member, participating in social activities, organizing events, attending weekly meetings, etc. However, I had never shared my private life with them but a few details, such as where I lived and where I studied. When I started dating I mentioned to a few people that if the relationship flourished I had to change my plans to go back to Brazil and form new plans to live in Canada. Even the decisions I faced involving this new journey that I was about to embark was different than theirs. I never talked about getting married, going shopping, using make-up like other girls of my age. I talked about the importance of my work at the centre and how I would use it when I left Canada, but this kind of conversation never attracted the attention of many people. Many of the members of the community 
questioned why I did not say that I was going to get married, and I told them that I was as surprised as they were with how everything happened, as it was just a City Hall wedding with our best friends. They were not happy with my answer and started acting distant. When I was removed from my activities as event planner, the president of the centre told me that the removal was short and temporary until the members got used to my marriage. He said that the members requested my removal because they felt betrayed for not announcing to everyone about my wedding.

A year later, when they had overcome the disappointment about my wedding, a particular member of the community explained why I was shut out of the community. She told me that they thought my husband forced me to get married and would take me to Algeria, his homeland, making me follow fanatical behaviours and keeping me there forever. I could understand that some members would think this way because they sought a reason for my short engagement; some asked me if I was pregnant, others asked me if I had bought my immigration status through marriage. My puzzlement was because everyone behaved the same way, appearing to share the same fear that I would be moving to another country. I have heard stories of individuals who followed different paths and were rejected by and expelled from their families. The difference is that there was no kin relation between the members of the Brazilian community besides their small families, consisting of couples with or without children and single individuals. I could not understand why they were 'overprotective' when I did not present the same loyalty to the community as other members did.

Taylor (2006) states that monocultural individuals overvalue their own beliefs and practices while undermining other worldviews. Could it be what was happening in this 
situation, that the members had developed a monocultural identity so strong that they lost track of other cultures and individual identities? I told one particular community member that even if I followed my husband to his country the consequences of my choice were my responsibility, no one else's. She said that they did not see things this way, and they would have suffered if something bad happened to me. It seemed that the members shared a deep mutual dependency that made them feel that they belonged to an extended and very close family. Since the members of the Brazilian community were ready to help with advice, money and even employment, they expected that all members accepted their rules of dependency. This dependency was to me a way to lose my own individuality and worldview. I considered them my friends and shared some things, but I could not share other things because I reserved them to share with my actual family only and no one else. Each relationship I had and the role that I had to 'play' was always very clear in my mind: if I had to listen to someone who needed some advice, I would be an advisor; if I had to teach something, I would be a teacher; and so on. However, I never imagined being a kin to another outside my family, and that was the expectation I perceived from many members. I remember an elderly couple saying constantly that they loved me, but they stopped this declaration after my marriage. Another person said she loved me because I gave her a few rides to go to the centre. When I moved to another neighbourhood and stopped picking her up, she changed her behaviour towards me. This was also very strange to me: people say 'I love you' so easily to one another in Canada. I never saw people in Brazil saying or writing 'I love you' to other people; but now I heard this all the time and to anyone. This custom can be observed in Valentine's Day, which in Brazil is only celebrated between couples who are dating or are married, not between friends and other types of 
relationships like in Canada. Within just a few weeks dating my husband, I bought him a book and wanted to make a dedication to him. I asked my English-speaking friend how I could end it; she said that I was to use 'with love, Eva.' I argued that I did not know if I was in love with him yet and that I was still sorting my feelings out, so I insisted, "how I translate com carinho [with fondness]?" She apologized and said that 'with love' was the only expression she knew. I remember wondering if Canadians did not know the difference between fondness and love, but at that time my vocabulary and resources to check a more suitable word to express my feelings were limited.

I continued my association with the centre for another year, trying to understand the familial sentimentalism that they had developed as a group. Members would come to me and ask when I was going to start a family or buy a house or start a new career. One can argue that these are normal questions that people ask to one another as 'small talk' conversations. However, in the centre, the members actually planned these things together and pressured those who resisted the decisions of the majority. I felt that I did not belong there because I did not share the same familial sentimentalism that united the group, and that sharing an ethnic identity was not enough reason to continue going to the centre. The activities I did at the Brazilian centre, such as providing services to newcomers and people in need, were very fulfilling, and I started looking for another community centre to continue the volunteering work.

\section{The Portuguese community}

In contrast with Brazil and Canada, Portugal is famous for the great expeditions to the New World in the sixteenth century (Kasher, 1997). The explorers colonized regions all 
over the world, including Brazil, some parts of the Caribbean Islands, Angola, and East Timor. However, the Portuguese migration to North America started much later. In fact, the most significant movements of Portuguese immigrants to Canada happened in the second half of the twentieth century (Higgs, 1982). The movement of independence from imperial domination through uprisings and great rebellions in the Portuguese's colonies resulted in limited social mobility, increasing unemployment, pushed for military conscriptions, and generated several forms of civil oppression. Young men were risking their lives going to the colonies to fight for the Empire, and they saw emigration opportunities as their way out of the military service, poverty and social stereotypes (Brown, 2012).

At the same time, Canada needed agricultural and manufacturing workers, among others, in response of the country's booming economy after the Second World War ended, and was 'shopping for foreign workforce' to fill the demands. The reason for 'shopping' was because the main regions that used to provide immigrants to Canada were also thriving. They were rebuilding their own countries, destroyed by the war, and did not see attractive reasons to emigrate (Libertucci, 2011). The Canadian government found a good source of workers in Portugal and its islands, the Azores and Madeira. After an initial resistance from António Salazar, Portugal's statesman, an agreement between the Department of Labour and the Portuguese government was made, which brought thousands of Portuguese to Canada in the decades of 1950s, 1960s, and 1970s (Higgs, 1982).

New immigrants were sent to farms across the country with pre-arranged contracts, but they were responsible for their travelling expenses. Many of them did not have the funds available for their trips, so they borrowed money from their potential employers, who included the loans in the contracts (Rosa \& Teixeira, 2009). They honored their initial 
contracts, but once they paid their duties to their employers, they left. Many workers sought better options in larger cities, settling in Toronto, Montreal and Vancouver, among others. The work conditions and climate contrasts from the tropical homeland were the biggest incentives to change the rural life from where they came to urban areas (Libertucci, 2011). There, they found temporary housing and work, and prepared the way for the migration of their families as well. The majority of the immigrants were married men, and under the family reunification policy, they sponsored large numbers of relatives, which shaped the formation of their communities in Canada (Rosa \& Teixeira, 2009).

The Toronto Portuguese community centre was founded in the 1960s and had the purpose to help Portuguese immigrants who prefer to connect with their own ethnic group rather than mainstream groups. During the first two decades, the centre also received Brazilians, Spaniards and Italians who attended its social activities. Once these ethnic groups had a sufficient number of members, they opened up their own centres, in which they embraced their own cultural practices. At that point, the Portuguese members did not compromise to maintain the members of other ethnic groups with them, since the customs and traditions of each ethnic group were too distinct to accommodate. Then, the Canadianborn children started to grow up and speak English only, and started to leave the centre. To keep their children as members, the board of directors created parallel English-speaking activities so their children and grandchildren who were living in the mainstream culture could gather with them at the centre.

When I joined the centre in 2005, I asked a few members why many parents would speak English with their children if they wanted to keep them in the Portuguese culture. They all told me that elementary school teachers advised them to speak only English with 
their children so they could do better at school. This information differs from what my English teacher said about her having to learn Portuguese because she lived in Toronto's Little Portugal neighbourhood. She was a West Indian descendant and could not speak Portuguese, but she learned how to write and read it. Nevertheless, I observed that the attempt to keep these English-speaking members did not achieve the aim the centre wanted. They left regardless of what language the events were used. However, the English activities attracted non-Portuguese members and many of them came because they liked the Portuguese culture. I also noticed that the Portuguese have become more receptive to other ethnic members than they had been in the beginning of my arrival at the centre. Through this is outside the topic of my study, this made me wonder as to what new elements have been developed in the centre with the influence of diverse ethnic members among the Portuguese members.

Differently from the Brazilian members, the Portuguese members had settled down and had formed families by the time I affiliated with the centre. Many members celebrated special occasions with their own families and there was no pressure to participate in all centre's events. They did not expect that all members would participate in all events, although they liked it when some members brought their families to the centre's events. For example, at Christmas and during Easter holidays, there are especial programs for the members and their families. The centre receives several visitors who are relatives or friends of members. English-speaking friends of the community also seek the centre to participate in these events and many others that are organized so the members can socialize with one another. 
Although these social activities are frequent and the centre has weekly programs, I have not perceived the same familial sensibility that existed among the Brazilians. It seems that the members understand that even though the centre's gatherings are an important part of their social life, they divide their attention with other activities outside of the centre as well. In summer times, some families enjoy their holidays in cottages, camping activities, and travelling. In winter times, some families leave the cold weather to go to warmer places, such as Portugal, Brazil or the southern regions of the United States. Thus, the members are constantly negotiating how they will deal with absentia of directors and event organizers so the centre keeps its busy agenda throughout the year. Aside from the president, who is chosen every 5 or 6 years, the board of directors rotates every year and they have the chance to work in different sections of the centre and serve the many needs of its members and friends.

Although I knew a few members of the Portuguese centre, I was not invited to fill a position right away as was the case with the Brazilian centre. My visits were infrequent to the Portuguese centre because I was also visiting other centres to see if I could fit there better. These centres were non-Portuguese-speaking, although a few of them were not part of the mainstream culture. I visited a centre, of which some of the members could have come from the Caribbean Islands or some parts of Africa, and I felt at home. They were friendly, pleasant to be with, and treated me as if I was an old friend who was coming back after a few years away. They needed some help to manage some of the sections and my leadership skills were welcomed.

At the same time, a new board of directors of the Portuguese centre was being chosen to start in the beginning of the following year and one of my friends, who was a 
member of the nominations committee, suggested my name to substitute for her on managing the youth section. Since I had not committed to the other centre yet, I accepted the invitation and became an official member of the centre. I was happy working among the Portuguese members and their customs were familiar to me, especially the language. For example, gaúchos conjugate the second person(s) (you) like the Portuguese (tu-singular and vós-plural). The Portuguese members also use a few expressions that are offensive to Brazilians, such as rapariga, which means little girl to Portuguese members while the term means woman of low morals to Brazilians. When I heard these expressions for the first few times, it took me a few moments to realize that their meaning had not the intent to offend but was the way their Portuguese language was. After a while I became aware of the small differences that the Portuguese culture had from what I was used to, and I adjusted to them. I fit better among the Portuguese members because I do not feel pressured to identify myself with them. I share what I want to share and feel that what I want to keep of my individual characteristics is respected as well. For example, they seem to expect that since my husband is not involved with the centre like I am, I cannot commit to attend all the events. They do not judge my lifestyle or invade my personal preferences and choices.

After 10 years as a member of the centre, I perceived that the Portuguese members had changed. They are less reserved and abrupt in their interaction with one another and more receptive to non-Portuguese members. They want to do more social activities together instead of being with their own families, which has prompted the board of directors to organize more events to promote these gatherings. Although they have expectations that a great number of members participate in these events, these expectations are moderate and are not imposed on the members. The organizers do not 
pressure the members to be in the events, and they accommodate them according to the response they receive from past experiences. For example, a director organized a reception for women so they could interact more with one another, however, only a small number of women attended. A few weeks later, she organized a breakfast and invited men to attend the event too, and the outcome was that many men attended it and the number of women also increased. She considered the second event an astounding success and has already scheduled another program for the fall.

When I wanted to organize a five-day series of activities for children a few years ago, as a director of the children's section, my partner at the centre told me that she had organized a similar program in the past and that parents did not bring their children during the week, and anticipated that organizing the event would be disappointing again. Then I suggested that we have the event in five-weeks - one day per weekend, instead of weekdays. I presented the plan to the board of director to receive the necessary approval and support. They told me that this schedule was unusual, but they supported the idea. The event was so successful that the directors and parents requested that the event becomes an annual program for children.

\section{Discussion}

Based on my experiences with the Brazilian community in Toronto, the members of the Brazilian centre have acquired a unique cultural identity. In an attempt to deal with the loss of their families upon migration, they created a type of familial sentimentalism to help them survive in a distinct cultural society. This characteristic creates limitations that a multicultural individual cannot accept. To them, the need to navigate the norms and values 
of different ethnic and cultural groups are part of their identity. They recognize the different influences that they receive through their own heritage, which is their ethnic identity, and the mainstream culture, which blends with their own culture and form their cultural identity. This recognition helps them to negotiate and integrate in the many cultures they navigate. For example, my children have Brazilian and Algerian ethnic identity although they were born in Canada, which also makes them Canadian. They need to learn Portuguese, Arabic and Kabyle to speak with their relatives as well as English, which is their own native language, to speak with the locals where they live. Since my husband and I, as their parents, have lived in Canada for many years and have blended our customs to live as a married couple, the culture they have at home is not 'pure' Brazilian or 'pure' Algerian, but a mix of cultures also influenced by the Canadian culture.

My children have developed a multicultural identity in order to navigate among all the ethnic and cultural diversity they live with. The awareness of having a multicultural identity helps my children feel that they belong to a multicultural society like Canada. Depending on who they are relating to, they may have to identify themselves with them in order to maintain a connection with the moment when the exchange contact is being made. This identification is possible because of the ability they developed in living at the margins of each culture. Among Brazilians, they are Brazilians, among Algerians, they are Algerians, among Canadians, they are Canadians, and at any time they will be telling the truth about having these ethnic identities. They can also claim the opposite if they do not feel like belonging to any of these, which they can feel entitled to do since the multicultural identity does not limit an individual to belong to one specific group. 
I developed my multicultural identity over the years when I was moving from one state to another in Brazil, even though I was not aware of it. In each region where I lived, I observed and integrated some of the cultural characteristics of the locals. Consequently, I redefined my own characteristics to fit well into these cultures. I could not belong in any of them, however, that was never the intention because living at the margins of these cultures as an observer was satisfying. When I faced a community that I felt imposed its cultural identification on me, I rejected it. This rejection was caused by the fact that being a multicultural individual, I felt that I could not meet the monoculturalism that the Brazilian community members wanted from me. If I acted according to their expectations, I could not navigate into another culture as I saw fit. I would have had to settle down with them, which I was not interested in doing.

The Portuguese community, on the contrary, had not challenged me to become one of them. Also, they received many more influences from other ethnic members over the years. When I associated with the Brazilians members, the centre existed for only 10 years, while the Portuguese centre existed for 40 years by the time I became a member. This could be one of the reasons why I could not perceive a defined cultural identity, although evidently they have one. This more flexible identity has allowed me to settle down so far and gives me the freedom to move again if I should feel the need to do so.

Nevertheless, I have to consider the possibility that I could fit in the Portuguese community because as a Brazilian I am a 'foreigner' to its members. I do not face any pressure to belong to the group, which frees me to navigate in and out of the community as I wish, and my involvement in the centre is accepted as long as I am willing to be there. However, I could not fit within the Brazilian community because the possibility to navigate 
in and out of the community is not possible. The pressure to belong to the community and share the same values and norms is greater there, and staying at the margins of the cultural identity is not acceptable because of the strong cultural identity they have developed in order to adjust to the new homeland. Thus my reactions and experiences are in keeping with the idea of multicultural identity, as discussed in the literature review and expanded here, since the concept of one living at margins of a culture has not yet been fully developed in ethnic and cultural studies.

Another identity I have developed and became aware of is a humanitarian one, which started at the Brazilian centre but I could explore more freely and fully at the Portuguese centre. The first factor that helped me to commit to the Portuguese centre was the opportunity to explore my leadership skills while helping other people. I did not stay working with the youth for long, but I could try other positions until I started working with children. This position was even more suitable to my identity because I could create more projects and develop my own expectations independent from the members' expectations to children's activities. Since multicultural individuals negotiate and integrate different values and norms, they also have internalized many of them and formed their own, which define who they are. When they are prevented from moving from their external and internal values and norms, they feel unsettled and want to move on. This was a part of my experiences in the Brazilian and Portuguese communities, and forms my multicultural identity and sense of belonging. 


\section{Conclusion and future work}

Ethnic identity varies according to the dimension of the identity one wants to claim. Along the national spectrum I am Brazilian and in a regional spectrum I am gaúcha. However, the experiences I had in moving to different places and receiving diversified cultural influences made me feel unclear of my cultural identity when I arrived in Canada. The Brazilian immigrants I was involved with found a way to harmonize their old cultural identity with their new identity developed through the immigration experiences acquired in Canada. The changes they experienced were gradual and perhaps imperceptible to them. My personal history was different though, and until I started this project, I had not understood the changes that I went through during my years of migration in Brazil. When I was challenged to fulfill different sets of expectations so I could fit in, I could not do so fully because it meant that I had to change who I had become through my own experiences.

Even though the Portuguese community has a distinct cultural identity, although it is not always clearly presented, I do not feel pressured to be like they are but have the freedom to explore my own identity. Once the pressure to belong to the group does not exist, since I can never claim to be Portuguese, I can stay at the margins of the Portuguese community without feeling obligated to embrace their cultural identity, whatever that is. Nevertheless, I have learned some of their customs and practices and adjusted my own worldviews somewhat, so I can harmoniously be part of their group until I feel compelled to navigate to another group.

In the course of this autoethnography, I tried to answer two main questions: why I did not fit among the Brazilians and why I fit better with the Portuguese community despite being Brazilian. The unique cultural identities that Brazilians and Portuguese 
developed as immigrants and how they dealt with their own challenges to adapt and integrate in Canada were the main factors that made me fit in the Portuguese community. I do not feel pressure to belong to the Portuguese community, and this flexibility gives me the freedom to navigate in and out of the community as I see fit, which matches the multicultural identity that I have developed through my own experiences as migrant in Brazil and Canada. Additionally, I suggested that multicultural individuals do not belong in defined cultural communities but they adjust their personal worldviews to the cultural group they relate to in order to fit there at the moment of the social exchange. This adjustment is only possible because they live at the margins of many cultures, which gives them the ability to navigate among different cultural groups in order to fulfill the need of movement that is part of the multicultural identity.

I have also presented many questions that, at this point, I cannot answer because I would need to do more extensive fieldwork in order to collect the appropriate data and examine its answers. The inquiry should be made among different ethnic groups, and participants should be in all generation categories. Two terms have been introduced that should be explored further: multicultural identity and familial sensibility. The first has not yet been explored from the perspective of someone standing at the margins of a culture as an observer rather than belonging to a specific culture as expected. The expectation is that each individual belongs to a defined ethnic and cultural group in order to feel well, since exclusion from a group leads to harmful consequences, especially related to mental health (Yampolsky, Amiot, \& de la Sablonnière, 2013). The second term was not considered in my literature review because I only realized the strong familial sensibility of the Brazilian 
group when I was trying to explain what identity the Brazilian members had developed over the years that made me feel too unsettled to belong to that group.

The discovery of new phenomena and terms during an ethnographic project is very common because of the element of grounded theory present in this type of research (Kendall, N. \& Thangaraj, 2013). Although the researcher prepares a hypothesis to establish the initial point to start the inquiry among the participants, s/he is also aware of the new elements s/he unveils during the period of the fieldwork. The work then becomes a continuous analysis until it is saturated and new elements cannot be found in the data (Creswell, 2013). Since this is just the beginning of an ethnographic project, there are more questions than answers, for example: Is multicultural identity a way to explain the confusion that people seem to manifest about identity and belonging in Canada? Can many other people really claim that they live at the margins of ethnic and cultural groups? Have multicultural individuals developed a common identity that make them part of one culture not yet defined because data has not been collected with the purpose of exploring this common identity? As I already said I cannot answer these questions because the biographical data I have provided here does not provide the answers. Hence, this is the first step collected toward a larger qualitative study on multicultural identity and belonging. 


\section{References}

Barbosa, R. (2009). Brazilian immigration to Canada. Canadian Ethnic Studies, 41(1), 215225. Retrieved from http://muse.jhu.edu.ezproxy.lib.ryerson.ca/journals/canadian_ethnic_studies/v041/ 41.1-2.barbosa.html

Barnard, A., \& Spencer, J. (Eds.). (2002). Encyclopedia of social and cultural anthropology. Florence, KY: Routledge. Retrieved from http://site.ebrary.com.ezproxy.lib.ryerson.ca/lib/oculryerson/detail.action?docID=1 0166525

Bassanezi, M. S. (1996). Imigrações internatiocionais no Brasil: um panorama histórico. In N. L. Patarra (Ed.), Emigração e imigração internacionais no Brasil contemporâneo (pp. 1-38). Campinas, SP: Fundo de População das Nações Unidas.

Bauder, H. (Ed.). (2012). Immigration Dialect: Imagining Community, Economy and Nation. Toronto: University of Toronto Press.

Berquó, E. (2003). Evolução demográfica. In I. Sachs, J, Wilheim, \& P. S. Pinheiro (Eds.), Brasil: um século de transformações (pp. 16-37). São Paulo, SP: Editora Schwarcz.

Berry, J. W., \& Sam, D. L. (1997). Acculturation and adaptation. In J. W. Berry, M. H. Seagull, C. Kagitcibasi (Eds.), Handbook of cross-cultural psychology: social behavior and applications, vol. 3, (pp. 291-327). Needham Heights, MA: Allyn and Bacon.

Brasch, K. (2007). Finding their place in the world: Brazilian migrant identities in an interconnected world (Order No. NR39658). Available from ProQuest Dissertations \& Theses A\&I; ProQuest Dissertations \& Theses Global; ProQuest Sociology Collection. (304755637). Retrieved from http://ezproxy.lib.ryerson.ca/login?url=http://search.proquest.com/docview/30475 5637? accountid=13631

Brown, T. (2012). The sun rises for everyone: Portuguese heritage in Toronto. Heritage Toronto. Retrieved from http://heritagetoronto.org/the-sun-rises-for-everyoneportuguese-heritage-in-toronto/

Cohen, R, (1978). Ethnicity: problem and focus in Anthropology. Annual Review of Anthropology, 7, 379-403.

Crawford, L. (1996). Personal ethnography. Communication Monographs, 63, 158-170.

Dana, R. H. (1998). Understanding cultural identity in intervention and assessment. Thousand Oaks, CA: Sage. 
David, E. (2006). Biculturalism. In Y. Jackson (Ed.), Encyclopedia of multicultural psychology. (pp. 67-69). Thousand Oaks, CA: Sage. doi: http://dx.doi.org/10.4135/9781412952668.n31

Denzin, N. K. (1997). Interpretative ethnography: ethnographic practices for the $21^{\text {st }}$ century. Thousands Oaks, CA: Sage.

Downie, M., Koestner, R., ElGeledi, S., \& Cree, K. (2004). The impact of cultural internalization and integration on well-being among tri-cultural individuals. Personality and Social Psychology Bulletin, 30(3), 1-10. Retrieved from http://selfdeterminationtheory.org/SDT/documents/2004_DownieKoestnerElgeledi Cree_PSPB.pdf

Dzialo, M. C., Shank, S. E., \& Smith, D. C. (1993). Atlantic and Pacific coasts' labor markets hit hard in early 1990's. Monthly Labor Review, 32-39.

Eddy, M. D. (2004). Fallible or inerrant?: a belated review of the 'Constructivist Bible'. In J. Golinski (Ed.), Making natural knowledge: constructivism and the history of science, pp. 93-98. British Journal for the History of Science, 37(1).

Ellis, C., Adams, T., \& Bochner, A. (2011). Autoethnography: an overview. Forum: Qualitative Social Research, 12(1), 1-18.

Fearn, T. (2006). A sense of belonging: supporting healthy child development in Aboriginal families. Toronto, ON: Ontario Prevention Clearinghouse. Retrieved from http://www.beststart.org/resources/hlthy_chld_dev/pdf/aboriginal_manual.pdf

Friedman, W. J. (2004). Time in autobiographical memory. Social Cognition, 22(5), 591-605. Retrieved from http://ezproxy.lib.ryerson.ca/login?url=http://search.proquest.com/docview/22966 8675 ?accountid=13631

Geetz, C. (1973). The interpretation of culture. New York, NY: Basic Books.

Giguère, B., Lalonde, R., and Lou, E. (2010). Living at the crossroads of cultural worlds: the experience of normative conflicts by second generation immigrant youth. Social and Personality Psychology Compass 4(1), 14-29.

Goodall, H.L., Jr. (2000). Writing the new ethnography. Walnut Creek, CA: AltaMira Press.

Government of Canada. (2014, Nov. 25). Canadian Multiculturalism Act (R.S.C., 1985, c. 24 (4th Supp.), [Part III]. Retrieved from http://laws-lois.justice.gc.ca/eng/acts/c-18.7/

Goza, F. (1994). Brazilian immigration to North America. The International Migration Review, 28(1), 136. Retrieved from 
http://ezproxy.lib.ryerson.ca/login?url=http://search.proquest.com/docview/21527 9035? accountid=13631

Green, J. B. (2003). Family theory \& therapy: exploring an evolving field. Pacific Grove, CA: Thomson, Brooks \& Cole.

Haritatos, J., and Benet-Martínez, V. (2002). Bicultural identities: the interface of cultural, personality, and socio-cognitive processes. Journal of Research in Personality, 36(6), 598-606. Retrieved from http://www.sciencedirect.com/science/article/pii/S009265660200510X

Harter, S., and Monsour, A. (1992). Development analysis of conflict caused by opposing attributes in the adolescent self-portrait. Developmental Psychology, 28 (2), 251-260.

Harter, S., \& Whitesell, N. R. (2003). Beyond the debate: why some adolescents report stable self-worth over time and situation, whereas others report changes in selfworth. Journal of Personality,71, 1027-1058.

Haslam, S. A., Jetten, J., Postmes, T., \& Haslam, C. (2009). Social identity, health and wellbeing: an emerging agenda for applied psychology. Applied Psychology: An International Review, 58, 1-23.

Hawkins, F. (1988). Canada and immigration: public policy and public concern. Montreal: McGill-Queen's University Press.

Heath, J. A., \& Ciscel, D. H. (1988). Patriarchy, family structure and the exploitation of women's labor. Journal of Economic Issues, 22(3), 781-794.

Higgs, D. (1982). The Portuguese in Canada. Library and Archives Canada, 2, 1-20. Retrieved from http://www.collectionscanada.gc.ca/cha-shc/008004-119.01-e.php?\&b_id=E2\&ps_nbr=1\&brws=y\&\&page_id=E-2-EN-

4667355\&\&PHPSESSID=ncvsn87i5a8425m11nn95muob3

Hogg, M. A. (2009). Managing self-uncertainty through group identification. Psychological Inquiry, 20, 221-224.

Holland, A. C. \& Kensinger, E. A. (2010). Emotion and autobiographical memory. Physics of Life Reviews, 7(1). 88-131. Retrieved from http://www.beststart.org/resources/hlthy_chld_dev/pdf/aboriginal_manual.pdf

Iyall Smith, K. E. (2008). Hybrid identities: theoretical examinations. In K. E. Iyall Smith and P. Leavy (Eds.), Hybrid identities: theoretical and empirical examinations, (pp. 3-11). Boston: Brill. 
Jantzen, L. (2009). Who is the second generation? A description of their ethnic origins and visible minority composition by age. Canadian Diversity, 6, 7-12. Retrieved from http://www.academia.edu/4467630/Who_Lives_at_Home_Ethnic_Variations_among_ Second_Generation_Young_Adults

Kasher, R. J. (1997). Passport's guide to ethnic Toronto: a complete guide to the many faces \& cultures of Toronto. Chicago, IL: Passport Books, a division of NTC Publishing Group.

Kelley, N. \& Trebilcock, M. (2010). The making of the mosaic: a history of Canadian immigration policy ( $2^{\text {nd }}$ ed.). Toronto: University of Toronto Press.

Kendall, N. \& Thangaraj, M. (2013). Ethnography. In A. A. Trainor \& E. Graue (Eds.), Reviewing qualitative research in the social sciences (pp. 82-107). New York, NY: Routledge.

Klinger, E. (1998). The search for meaning in evolutionary perspective and its clinical implications. In P. Wong \& P. Fry (Eds.), The human quest for meaning: a handbook of psychological research and clinical applications, (pp. 27-50). Mahwah, NJ: Lawrence Erlbaum.

Knowles, V. (2007). Strangers at our gates: Canadian immigration and immigration policy, 1540-2006. Toronto, ON: Dundurn.

Lambert, N., Stillman, T., Hicks, J., Kamble, S., Baumeister, R., \& Fincham, F. (2013). To belong is to matter: sense of belonging enhances meaning in life. Personality and Social Psychology Bulletin, 39(11), 1418-1427. doi:10.1177/0146167213499186

Lewis-Beck, M. S., Bryman, A., \& Liao, T. F. (Eds.). (2004). Encyclopedia of social science research methods. (Vols. 1-3). Thousand Oaks, CA: Sage. doi:

http://dx.doi.org/10.4135/9781412950589

Libertucci, A. (2011). Schooling in Little Portugal: the Portuguese experience. Retrieved from http://www.collectionscanada.gc.ca/obj/thesescanada/vol2/OTU/TC-OTU29478.pdf

Magocsi, P. R. (Ed.). (2015). Encyclopedia of Canada's peoples. Toronto: University of Toronto Press. Retrieved from https://books.google.ca/books?id=svCMBgAAQBAJ\&pg=PT809\&dq=brazilian+settle ment+in+canada+history\&hl=en\&sa=X\&ved=0CB4Q6wEwAGoVChMIys7A6JTyxgIVS $x$ mSCh2j0QzA\#v=onepage\&q=brazilian\%20settlement\%20in\%20canada\%20history\& $\mathrm{f}=$ false

Mandela, N. (1995). Long walk to freedom: the autobiography of Nelson Mandela. New York: Back Bay Books: Little, Brown and Company. 
McMillan, D. W., \& Chavis, D. M. (1986). Sense of community: A definition and theory. Journal of Community Psychology, 14(1), 6-23.

Mead, M. (1928). Coming of age in Samoa. New York: William Morrow and Co.

Merrill, B., \& West, L. (2009). On being a biographical researcher. In Using biographical methods in social research. (pp. 179-191). London, England: Sage Publications, Ltd. doi: http://dx.doi.org/10.4135/9780857028990.d189

Noels, K. A., Pon, G., and Clément, R. (1996). Language, identity and adjustment: the role of linguistic self-confidence in the acculturation process. Journal of Language and Social Psychology, 15, 246-264.

Nunes, R. B. (2002, October). Brazilian emigration: a late 20th century phenomenon. Paper presented at the Congress of the Canadian Association for Latin American and Caribbean Studies. Montreal, Quebec, Canada.

Phinney, J. (1989). Stages of ethnic identity development in minority group adolescents. Journal of Early Adolescence, 9, 34-39.

Pieterse, J. N. (2001). Hybridity, so what? The anti-hybridity backlash and the riddles of recognition. Theory Culture and Society,18(2-3), 219-245.

Poirier, W. (2012). A sense of belonging: report on social inclusion at Mohawk College. Hamilton, ON: Mohawk College. Retrieved from http://www.mohawkcollege.ca/Assets/Documents/Reports/sense-of-belongingreport-on-social-inclusion-Mohawk.pdf

Poulos, C. (2013). Autoethnography. In A. A. Trainor \& E. Graue (Eds.), Reviewing qualitative research in the social sciences (pp. 82-107). New York, NY: Routledge.

Roberts, B. (2002). Introduction: biographical research. In Biographical Research. (pp. 117). London: Open University Press. Retrieved from https://student.cc.uoc.gr/uploadFiles/1110\%CE\%A5004\%CE\%9A/BIOGR1_Biographical\%20research.pdf

Rocher, G. (2015). Culture. In Historica Canada. Retrieved from http://www.thecanadianencyclopedia.ca/en/article/culture/

Rosa, V. \& Teixeira, C. (2009). The Portuguese in Canada: Diasporic challenges and adjustment. Toronto: University of Toronto Press.

Sam, D. L., \& Berry, J. W. (Eds). (2006). Cambridge handbook of acculturation psychology. Cambridge: Cambridge University Press. 
Sen, A. (2006). Identity and violence: the illusion of destiny. New York, NY: W.W. Norton \& Co.

Shirley, R. (1999). Brazilians. In P. R. Magocsi (Ed.), Encyclopedia of Canada's peoples (pp. 273-282. Toronto: Multicultural History Society.

Smith, H. (2008). Biculturalism. In J. González (Ed.), Encyclopedia of bilingual education. (pp. 66-68). Thousand Oaks, CA: Sage. doi: http://dx.doi.org/10.4135/9781412963985.n31

Statistics Canada. (2010). Community belonging. Retrieved from http://www.statcan.gc.ca/pub/82-229-x/2009001/envir/cob-eng.htm

Statistics Canada. (2012). Facts and figures 2011 - Immigration overview: permanent and temporary residents. Retrieved from http://www.cic.gc.ca/english/resources/statistics/facts2011/permanent/10.asp

Statistics Canada. (2014). Generation status: Canadian-born children of immigrants. [Catalogue no. 99-010-X2011003]. Retrieved from http://www12.statcan.gc.ca/nhsenm/2011/as-sa/99-010-x/99-010-x2011003_2-eng.cfm

Statistics Canada. (2015). Sense of belonging to Canada, the province of residence and the local community. Retrieved from http://www.statcan.gc.ca/pub/89-652-x/89-652x2015004-eng.htm\#tbl1

Stearns, J. (Director \& Producer). (2010). One Big Hapa Family [DVD]. Vancouver, BC: Meditating Bunny Studio Inc.

Steger, M. F., Frazier, P., Oishi, S., \& Kaler, M. (2006). The meaning in life questionnaire: assessing the presence of and search for meaning in life. Journal of Counseling Psychology, 53, 80-93.

Stillman, T. F., Baumeister, R. F., Lambert, N. M., Crescioni, A. W., DeWall, C. N., \& Fincham, F. D. (2009). Alone and without meaning: Life loses meaning following social exclusion. Journal of Experimental Social Psychology, 45, 686-694.

Tadmor, C. T., \& Tetlock, P. E. (2006). Biculturalism: a model of the effects of second-culture exposure on acculturation and integrative complexity. Journal of Cross-Cultural Psychology, 37, 173-190.

Taylor, J. (2006). Ethnocentric monoculturalism. In Y. Jackson (Ed.), Encyclopedia of multicultural psychology, (pp. 204-205). Thousand Oaks, CA: Sage. doi: http://dx.doi.org/10.4135/9781412952668.n105 
Tedlock, B. (2003). Ethnography and ethnographic representations. In N. Denzin and Y. S. Lincoln (Eds.), Strategies of qualitative inquiry (pp.165-213). Thousand Oaks, CA: Sage.

Teixeira, C. (2007). Toronto's Little Portugal: a neighbourhood in transition. Centre for Urban and Community Services, 35, 1-8. Retrieved from http://www.urbancentre.utoronto.ca/pdfs/researchbulletins/CUCSRB35Teixeira.pdf

Teixeira, C., Li, W., Kobayashi, A. (Eds.). (2012). Immigrant geographies of North American cities. Don Mills, ON: Oxford University Press.

Twenge, J. M., Catanese, K. R., \& Baumeister, R. F. (2003). Social exclusion and the deconstructed state: time perception, meaninglessness, lethargy, lack of emotion, and self-awareness. Journal of Personality and Social Psychology, 85, 409-423.

Vallee, F. G., Schwartz, M., \& Darknell, F. (1957). Ethnic assimilation and differentiation in Canada. The Canadian Journal of Economics and Political Science / Revue Canadienne d'Economique Et De Science Politique, 23(4), 540-549.

Verkuyten, M. (2011). Assimilation ideology and outgroup attitudes among ethnic majority members. Group Processes \& Intergroup Relations, 14(6), 789-806. doi:10.1177/1368430211398506

Vertovec, S. (2007). Super-diversity and its implications. Ethnic and Racial Studies, 30(6), 1024-1054. Retrieved from http://www.uio.no/studier/emner/sv/sai/SOSANT2525/h14/pensumliste/vertovec _super-diversity.pdf

Vidal, S. M. (2000). Brasileiros no Canadá: a descoberta de novos caminhos (Doctoral Dissertation). Pontifícia Universidade Católica de São Paulo, Sociology Department, São Paulo, São Paulo, Brasil.

Williams, K. D., Cheung, C. K. T., \& Choi, W. (2000). CyberOstracism: effects of being ignored over the internet. Journal of Personality and Social Psychology, 79, 748-762.

Yampolsky, M. A., Amiot, C. E., \& de la Sablonnière, R. (2013). Multicultural identity integration and well-being: A qualitative exploration of variations in narrative coherence and multicultural identification. Frontiers in Psychology, 4, 126. doi:10.3389/fpsyg.2013.00126 